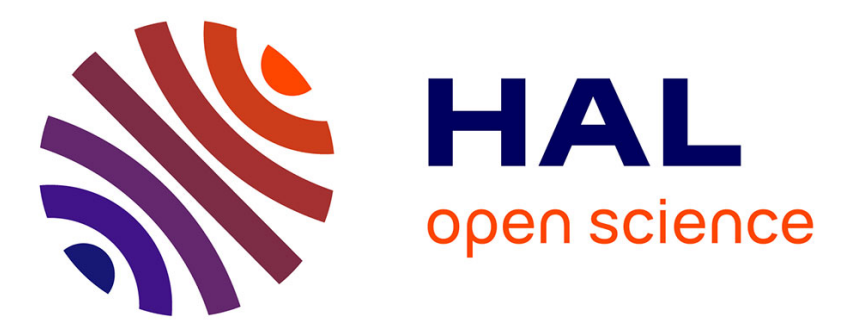

\title{
Relation between students' reflection levels and their inquiry learning outcomes
}

\author{
Mario Mäeots, Leo Siiman, Külli Kori, Margus Pedaste
}

\section{To cite this version:}

Mario Mäeots, Leo Siiman, Külli Kori, Margus Pedaste. Relation between students' reflection levels and their inquiry learning outcomes. 8th International Conference on Education and New Learning Technologies (EDULEARN2016), Jul 2016, Barcelona, Spain. hal-01399062

\section{HAL Id: hal-01399062 \\ https://telearn.archives-ouvertes.fr/hal-01399062}

Submitted on 18 Nov 2016

HAL is a multi-disciplinary open access archive for the deposit and dissemination of scientific research documents, whether they are published or not. The documents may come from teaching and research institutions in France or abroad, or from public or private research centers.
L'archive ouverte pluridisciplinaire HAL, est destinée au dépôt et à la diffusion de documents scientifiques de niveau recherche, publiés ou non, émanant des établissements d'enseignement et de recherche français ou étrangers, des laboratoires publics ou privés. 


\title{
RELATION BETWEEN STUDENTS' REFLECTION LEVELS AND THEIR INQUIRY LEARNING OUTCOMES
}

\author{
Mario Mäeots, Leo Siiman, Külli Kori, Margus Pedaste \\ University of Tartu (ESTONIA)
}

\begin{abstract}
In this study we aimed to identify the relation between students' reflection levels and their inquiry learning outcomes (i.e. their formulated conclusions) after conducting a complete inquiry cycle in an online Go-Lab Inquiry Learning Space (ILS). We expected that students exhibiting a higher reflection level would be more experienced in formulating higher quality conclusions than students at a lower reflection level. Forty-three students from the 9th grade with an average age of 15 years from two Estonian public schools participated in this study. During the interventions students worked with a chemistry-based ILS called "What does pH measure?" Students were given a pre-defined problem to be solved by following an inquiry cycle. In each phase students had tasks to perform which led to concrete learning outcomes. The students used specific application called Conclusion Tool to state their conclusions and used Reflection Tool to answer two open-ended reflective questions to reflect on their study process. The results suggest that students who reflect at a higher reflection level are more successful in formulating higher quality inquiry outcomes such as hypotheses, observations and conclusions. Therefore it seems that reflection should be part of the learning process in order to support students to achieve higher quality inquiry learning outcomes.
\end{abstract}

Keywords: inquiry-based learning, online learning environments, reflection.

\section{INTRODUCTION}

\subsection{Inquiry-based learning}

Inquiry-based learning is an approach to learning that aspires to engage students in authentic scientific discovery processes [1, 2]. It places emphasis on students as active learners and encourages them to follow their own questions and hypotheses to investigate scientific phenomena [3, 4]. Typical inquiry processes consist of several learning phases that can be organized in an inquiry cycle. A systematic literature review and synthesis of inquiry phases and cycles was performed by Pedaste et al. [5] and led to the identification of five main inquiry phases: Orientation, Conceptualization, Investigation, Conclusion and Discussion. In the current study we followed this inquiry cycle structure to design our intervention. In general, the inquiry cycle begins with the Orientation phase, which is a process of stimulating curiosity about a topic and identifying a research problem. Then follows the Conceptualization phase, where students formulate theory-based research questions and/or hypotheses. Next is the Investigation phase, which is a process of planning exploration or experimentation and collecting data for analysis. The fourth phase is the Conclusion phase, where students compare their interpretations of the data to their research questions and/or hypotheses in order to draw evidence-based conclusions. The Discussion phase, which involves communicating findings or reflecting on one's learning, can potentially occur at any time during inquiry or after all inquiry processes have been completed. In the present study, reflection occurred at the end of the inquiry activity (reflection on-action), when students looked back on what they did, why they did it so and what they would do differently next time.

\subsection{Reflection}

Reflection is a cognitive process to learn from previous learning experience [6, 7]. It encourages learners at any age to analyse what they have done during the learning process [8]. In order to achieve the best outcome of the reflection, then it has to be planned by the learner. But in the case of students at school it does not always occur spontaneously. It is mostly because students are not capable of reflecting on their learning without guidance [9]. Research has shown that guided reflection helps students to achieve higher quality of reflection [10], and if reflective activities' are embedded into the learning task (i.e. into the inquiry learning task), then it might have larger effect on learning [11]. In 
the current study, reflection was supported with a software learning application called the Reflection Tool [12], which was embedded into an online Inquiry Learning Space.

In education research there are several coding schemes proposed for assessing students' reflections. In the current study we followed the Poldner et al. [13] coding scheme. Their coding scheme distinguishes five levels of reflection (presented in hierarchical order): description (descriptions of the difficulties that the student had), justification (rationale or logical explanation for the difficulties), critique (explanation and evaluation of the difficulties), dialogue (critical review of different solutions or alternative methods) and transfer (how the next action becomes different or better than the previous action).

\subsection{Goal of the current study}

The current study aimed to identify the relation between students' reflection levels and their formulated conclusions after conducting a complete inquiry cycle in an online Inquiry Learning Space (ILS). Taking into consideration the aim of the current study the following research questions were addressed:

- What is the quality of the students' reflections after conducting a complete inquiry cycle?

- What is the quality of the students' conclusions after conducting a complete inquiry cycle?

- What is the relation between students' reflections and formulated conclusions?

\section{METHODS}

\subsection{Materials}

\subsubsection{Inquiry Learning Space}

An Inquiry Learning Space (ILS) is an online learning environment hosted by the Go-Lab Platform (see http://www.golabz.eu/spaces) that includes all the resources and instructional guidance to provide students with an engaging and effective inquiry learning experience. The EU funded project Go-Lab (see www.go-lab-project.eu) aims to open up online science laboratories (remote and virtual labs) for widespread use in school science education. An ILS integrates an online lab in a suitable pedagogical structure and with learning applications (apps) that support and guide inquiry processes [14]. The GoLab Platform also provides an authoring platform from which teachers or users can adapt existing ILSs or create new ones.

\subsubsection{Inquiry Learning Space "What does $\mathrm{pH}$ measure?"}

In the current study we designed a chemistry topic ILS called "What does pH measure?" based on the five phase inquiry cycle structure of Pedaste et al. [5]. The five phases in the ILS are Orientation, Conceptualization, Investigation, Conclusion and Discussion, and four Go-Lab inquiry apps were embedded in the ILS: a Hypothesis Scratchpad in the Conceptualization phase, an Observation Tool in the Investigation phase, a Conclusion Tool (see Fig. 1) in the Conclusion phase, and a Reflection Tool in the Discussion phase.

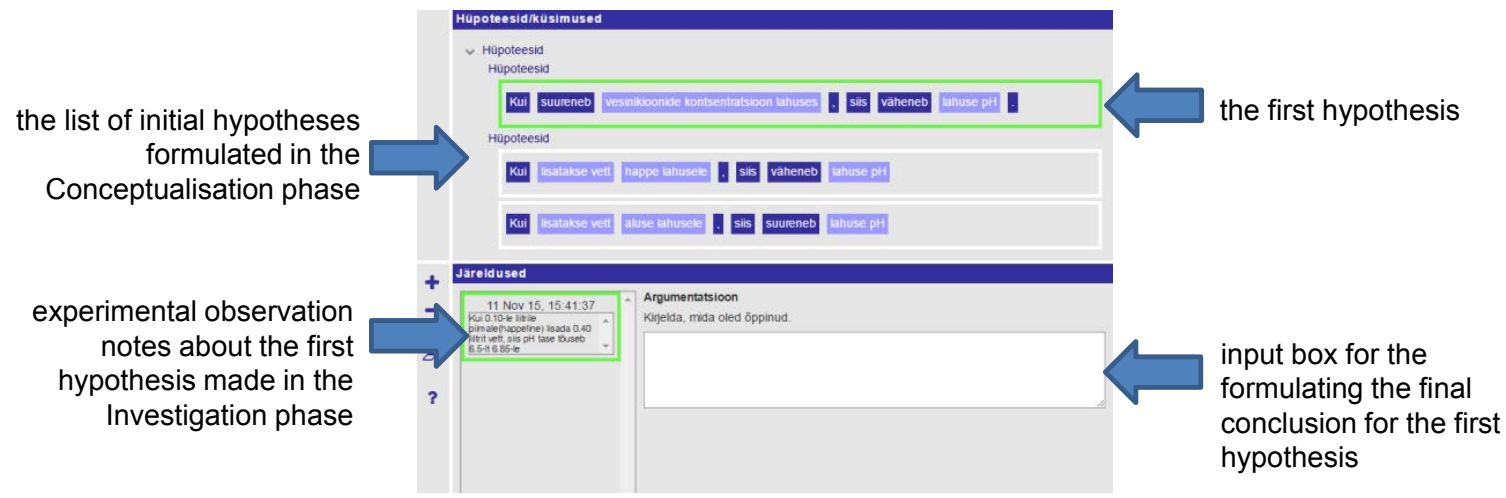

Figure 1. Screenshot of the Conclusion Tool in an ILS called "What does pH measure?" 
In the Orientation phase of the ILS, the chemistry topic of $\mathrm{pH}$ was introduced and two research questions posed to students: (1) What does $\mathrm{pH}$ measure? (2) How does the $\mathrm{pH}$ of an acidic or alkaline solution change when water is added to it? In the next phase, the Conceptualization phase, students were allowed to briefly interact with two virtual labs, "Acid-Base Solutions" and "pH Scale: Basics", created by the PhET project (http://phet.colorado.edu), and then instructed to formulate two hypotheses related to the two research questions presented to them during the Orientation phase. In the Investigation phase students were able to thoroughly interact with the two virtual labs to conduct experiments and record observations to find evidence for confirming or rejecting their hypotheses. In the Conclusion phase students were instructed to compare their observations to their initial hypotheses and state evidence-based conclusions. In the final phase, the Discussion phase, students were asked two reflection questions: (1) "Which inquiry phase was the most difficult for you and why?" and (2) "What would you do differently the next time you conduct an inquiry investigation?"

\subsection{Participants and procedure}

The sample consisted of forty-three students (average age of 15 years) from two $9^{\text {th }}$ grade classes. The gender distribution among students was 21 female students and 23 male students. The intervention was conducted during the current school year in November 2015 in two Estonian public schools during regular classroom hours. During the intervention students worked with a chemistrybased ILS called "What does pH measure?" The intervention was one school lesson (45 minutes).

\subsection{Coding students' reflections and conclusions}

The students' reflections and conclusions were analysed by two researchers using a rubric for identifying students' reflection levels (description, justification critique, dialogue and transfer) that was described in our previous work [12]. In the case of reflection levels the Cohen's kappa was 0.860 . Since one of the aims of conducting an inquiry-based learning activity is to test the hypothetical relation between independent and dependent variables by observations or experiments [15], the conclusion is a result of this inquiry activity, providing an evidence-based judgement about the formulated hypotheses. The hypotheses contain independent and dependent variables and the hypothetical relation between these variables $[16,17]$. Thus, in the current study we created a rubric that considers the structure of the hypotheses (Table 1 ).

Table 1. A rubric for assessing the quality of students' conclusions.

\begin{tabular}{|c|c|c|}
\hline Criteria & Description & Scoring \\
\hline \multirow[t]{2}{*}{ Consistency } & \multirow{2}{*}{$\begin{array}{l}\text { The conclusion is consistent if it derives from the } \\
\text { hypotheses formulated by the student in the } \\
\text { Conceptualization phase and considers the } \\
\text { experimental observation made in the Investigation } \\
\text { phase }\end{array}$} & $\begin{array}{l}0 \text { points - conclusion is not } \\
\text { consistent with the hypotheses }\end{array}$ \\
\hline & & $\begin{array}{l}1 \text { point - conclusion is } \\
\text { consistent with the hypotheses }\end{array}$ \\
\hline \multirow[t]{2}{*}{$\begin{array}{l}\text { Dependent } \\
\text { variable }\end{array}$} & \multirow{2}{*}{$\begin{array}{l}\text { Dependent variable results from the formulated } \\
\text { hypotheses (e.g., amount of hydrogen ions in the } \\
\text { solution) }\end{array}$} & $\begin{array}{l}0 \text { points - dependent variable } \\
\text { is missing }\end{array}$ \\
\hline & & $\begin{array}{l}1 \text { point - dependent variable is } \\
\text { present }\end{array}$ \\
\hline \multirow[t]{2}{*}{$\begin{array}{l}\text { Independent } \\
\text { variable }\end{array}$} & \multirow[t]{2}{*}{$\begin{array}{l}\text { Independent variable results from the formulated } \\
\text { hypotheses (e.g., } \mathrm{pH} \text { level of the solution) }\end{array}$} & $\begin{array}{l}0 \text { points - independent } \\
\text { variable is missing }\end{array}$ \\
\hline & & $\begin{array}{l}1 \text { point - independent variable } \\
\text { is present }\end{array}$ \\
\hline \multirow[t]{2}{*}{ Relation } & \multirow{2}{*}{$\begin{array}{l}\text { Relation between independent and dependent } \\
\text { variables is present and considers the } \\
\text { experimental observation made in the Investigation } \\
\text { phase (e.g., if the amount of the hydrogen ions } \\
\text { increases, then the pH level of solution decreases) }\end{array}$} & 0 points - relation is missing \\
\hline & & $\begin{array}{l}1 \text { point - relation considers the } \\
\text { hypotheses }\end{array}$ \\
\hline
\end{tabular}


The quality of students' conclusions was assessed by four criteria: consistency with hypotheses, presence of the dependent variable, presence of the independent variable, presence of a relation. The Cohen's kappa between two researchers was 0.839 .

\section{RESULTS AND DISCUSSION}

\subsection{Quality of students' reflections}

Students' were asked to reflect on two reflective questions. The first question focused on detecting difficulties ("Which inquiry phase was the most difficult for you and why?") that students encountered during the inquiry task, and the second question addressed conducting similar studies in the future ("What would you do differently the next time you conduct an inquiry investigation?"). The results of these reflections are reported in this section.

According to the results of analysing the students' answers of the first reflective question we identified that 15 students were at the description level and 28 of the 43 students were at the justification level (see Table 2). Disappointingly, the highest reflection levels (critique, dialogue and transfer) were not detected at all. Research has also described similar outcomes that students intend to reflect on lower level of reflections [18]. Thus, there is a need to guide students towards higher level of reflection [9]. In our study we formulated the first reflective question so that it has components like "the most difficult" and "why" that should guide students towards higher level of reflection. But still 15 students mentioned only the name of the inquiry phase which was the most difficult for them without explaining why it was difficult for them. The most frequently named phases by the students (some students pointed out two phases) at the description and justification reflection level were Conceptualisation (mentioned 18 times) and Investigation phase (mentioned 15 times). This is consistent with the research claiming that students meet obstacles in formulating hypotheses or conducting their experiments [1, 19]. Our analysis revealed that students mostly had three types of issues concerning hypotheses generation: (a) formulation issues (e.g., "I do not understand how to formulate hypotheses"); (b) time issues (e.g., "I spent longer time than expected"); and (c) topic-related issues (e.g., "I do not understand the topic"). Research suggests applying scaffolding for reducing obstacles that students are facing in conducting inquiry $[20,21]$.

Table 2. Distribution of students' reflection levels based on their reflections and examples of students' reflections $(n=43)$.

\begin{tabular}{|l|c|l|}
\hline $\begin{array}{l}\text { Reflection } \\
\text { level }\end{array}$ & $\begin{array}{l}\text { Number of } \\
\text { students }\end{array}$ & Examples of students' answers \\
\hline $\begin{array}{l}\text { Description } \\
\text { (descriptions of } \\
\text { the difficulties } \\
\text { that the student } \\
\text { had) }\end{array}$ & 15 & $\begin{array}{l}\text { Student A: "Experimenting was the most difficult for me" } \\
\text { Student B: "Everything was difficult for me" } \\
\text { Student C: "Making conclusions was the most difficult for me, but I } \\
\text { do not know why" }\end{array}$ \\
\hline $\begin{array}{l}\text { Justification } \\
\text { (rationale or } \\
\text { logical } \\
\text { explanation for } \\
\text { the difficulties) }\end{array}$ & 28 & $\begin{array}{l}\text { Student D: "I had difficulties in the hypotheses phase because it } \\
\text { took longer than expected" } \\
\text { Student E: "Hypotheses formulation and conclusion making was } \\
\text { the most difficult for me because I did not exactly understand how } \\
\text { to formulate these" } \\
\text { Student F: "For me the most difficult phase was experimenting. I } \\
\text { understood how the experiment goes, but I met difficulties in } \\
\text { writing my observations" }\end{array}$ \\
\hline
\end{tabular}

The second reflective question focused on the future aspects on inquiry. Thinking about the future is also related to the regulative inquiry processes which help students to plan, monitor, and evaluate all inquiry activities (e.g., planning the process of formulating conclusion) [22]. In the current study students were asked to think about what to do next time differently while conducting an inquiry investigation. Students' reflections were assessed taking into account the content of reflection described by Poldner et al. [13]. Students' reflections were classified based on their focus into four categories: (a) topic (next time will do something differently that considers the topic of task); (b) inquiry 
phase (next time will do something differently that considers inquiry phases); (c) learning (next time will do something differently that considers over all learning process); time (next time will do something differently that considers the time planning). Some students' reflection examples are presented below to give an idea of the four categories.

Some examples of students' reflections on future aspects:

- TOPIC: "I should consider more theory behind the topic".

- INQUIRY PHASE: "Next time I will do more notes. This will help me in the Investigation phase".

- TIME: "I will try to spend less time on the task".

- LEARNING: "I would prefer to do more collaborative type of work. I would like to discuss results with my classmates".

\subsection{Quality of students' conclusions}

In analysing conclusions we saw that usually students were able to formulate conclusions that were consistent with the formulated hypotheses $(74 \%)$, but sometimes they missed one or another component of the hypothesis (e.g., relation between independent and dependent variable). This means that most of the students considered their initial hypotheses and experimental results in formulating conclusions. It shows that students' have high level of general inquiry knowledge and they understand the coherence of the inquiry process [23]. Figure 2 describes the distribution of the quality of individual students' conclusions by four criteria (consistency, independent variable, dependent variable, relation).

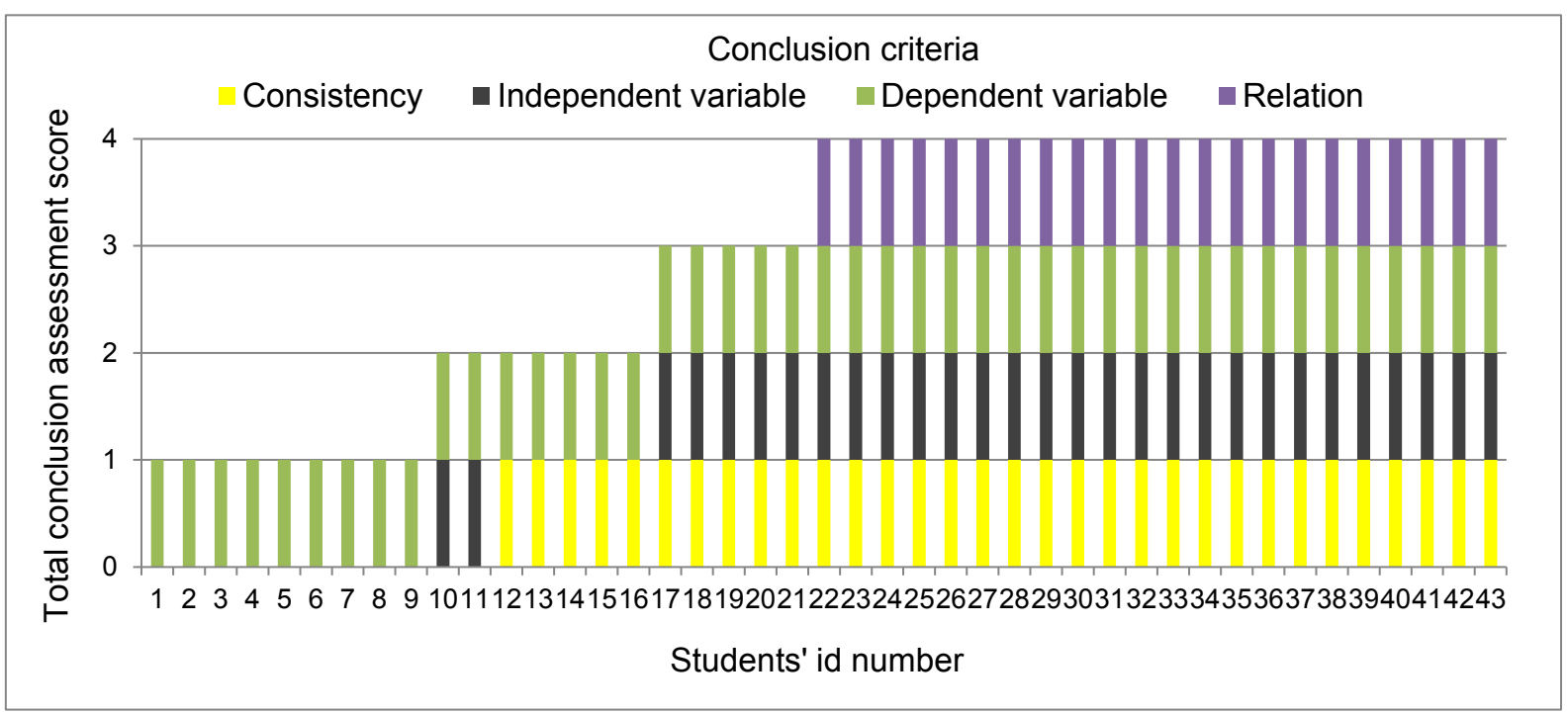

Figure 2. The quality of individual students' $(n=43)$ conclusions assessed according to the four criteria (consistency, independent variable, dependent variable, relation) described in Table 1. Individual student scores were sorted from lowest to highest.

All of the students' conclusions contained a construct that can be classified as a dependent variable. In the case of nine students the dependent variable was the only component of the conclusion that could be detected. An independent variable could be identified 29 times and was always together with a dependent variable. But if we look at the presence of a relation between independent and dependent variables in the students' generated conclusions, then a relation between variables was stated only 22 times. Our outcomes confirm the findings from the literature that students have difficulties in making conclusions using independent and dependent variable [1]. However, we still detected a positive correlation between the consistency of a conclusion and the overall quality of the conclusion $(\rho=0.796$; $\mathrm{p}<0.05)$. So it appears that if a student considers his/her initially formulated hypotheses and his/her experimental data, then there is higher possibility that the student will formulate a high quality conclusion. 


\subsection{Relation between students' reflections and formulated conclusions}

In order to study the relation between students' reflections and the conclusions they formulated, students were divided into two groups based on the quality of the conclusions. A non-parametric Mann-Whitney U-test revealed that the students who formulated conclusions at a high quality level also scored higher on the reflection level $(Z=-2.574 ; p<0.01)$. A moderate correlation $(\rho=0.420$; $p<0.005)$ was found between the quality of students' reflections and the consistency of their conclusions with their hypotheses. The results suggest that students who reflect at a higher reflection level are more successful in formulating high quality conclusions.

\section{CONCLUSIONS}

The current study aimed to identify the relation between students' reflection levels and their formulated conclusions after conducting a complete inquiry cycle in an online Inquiry Learning Space (ILS). Our results revealed that students show a rather low level of reflection quality (only the lower levels description and justification were detected). Students' reflections mostly considered formulationrelated, time-related and topic-related issues. The latter can be used as an input for creating suitable scaffolding for inquiry-based tasks. Also, students' reflected what they themselves would like to do differently next time when conducting inquiry-based activities. We detected four categories: time, inquiry phase, learning and topic. It is useful to note that students refer to the same difficulties that usually researchers indicate in their studies, and therefore shows these are critical issues that require attention. In addition to assessing students' reflections we analysed students' conclusions. The majority of the formulated conclusions were consistent with the initial hypotheses formulated by a student. Finally, we found a statistically significant difference between students who showed a high level of reflection and students who showed a low level of reflection when comparing the quality of the conclusions stated by these students. Therefore, it seems that reflection should be part of the learning process in order to support students in achieving higher quality inquiry learning outcomes.

\section{ACKNOWLEDGMENTS}

This study is funded by the European Union in the context of the Go-Lab project (Grant Agreement No. 317601) under the Information and Communication Technologies (ICT) theme of the $7^{\text {th }}$ Framework Programme for R\&D (FP7). This document does not represent the opinion of the European Union, and the European Union is not responsible for any use that might be made of its content.

\section{REFERENCES}

[1] de Jong, T., \& van Joolingen, W. R. (1998). Scientific discovery learning with computer simulations of conceptual domains. Review of Educational Research, 68,179-201. doi: 10.3102/00346543068002179

[2] Manlove, S., Lazonder, A. W., \& de Jong, T. (2006). Regulative support for collaborative scientific inquiry learning. Journal of Computer Assisted Learning, 22, 87-98. doi: 10.1111/j.1365-2729.2006.00162.x

[3] White, B. Y., \& Frederiksen, J. R. (1998). Inquiry, modeling, and metacognition: Making science accessible to all students. Cognition and Instruction, 16, 3-118. doi: 10.1207/s1532690xci1601_2

[4] Pedaste, M., \& Sarapuu, T. (2014). Design principles for support in developing students' transformative inquiry skills in web-based learning environments. Interactive Learning Environments, 22, 309-325.

[5] Pedaste, M., Mäeots, M., Siiman, L. A., de Jong, T., van Riesen, S. A., Kamp, E. T., \& ... Tsourlidaki, E. (2015). Review: Phases of inquiry-based learning: Definitions and the inquiry cycle. Educational Research Review, 14, 47-61.

[6] Moon, J. A. (2004). Reflection in learning and professional development. New York: Routledge.

[7] Schön, D. (1983). The reflective practitioner: How professionals think in action. New York: Basic Books. 
[8] Goodman, B., Linton, F., \& Gaimari, R. (2016). Encouraging Student Reflection and Articulation Using a Learning Companion: A Commentary. International Journal of Artificial Intelligence In Education, 26(1), 474-488. doi:10.1007/s40593-015-0041-4

[9] Kori, K., Pedaste, M., Leijen, Ä., \& Mäeots, M. (2014). Review: Supporting reflection in technology-enhanced learning. Educational Research Review, 1145-55. doi:10.1016/j.edurev.2013.11.003

[10] Leijen, Ä.; Valtna, K.; Leijen, D. A. J.; \& Pedaste, M. (2012). How to determine the quality of students' reflections? Studies in Higher Education, 37(2), 203-217.

[11] Pedaste, M., Mäeots, M., Leijen, Ä., \& Sarapuu, T. (2012). Improving students' inquiry skills through reflection and self-regulation scaffolds. Technology, Instruction, Cognition and Learning, 9, 81-95.

[12] Mäeots, M., Siiman, L., Kori, K., Eelmets, M., Pedaste, M., Anjewierden, A. (2016). The role of a reflection tool in enhancing students' reflection. In the proceedings of the $10^{\text {th }}$ annual International Technology, Education and Development Conference (INTED2016), pp. 18921900, doi: 10.21125/inted.2016.1394

[13] Poldner, E., Simons, P. R. J., Wijngaards, G., \& Van der Schaaf, M. F. (2012). Quantitative content analysis procedures to analyse students' reflective essays: A methodological review of psychometric and edumetric aspects. Educational Research Review, 7(1), 19-37.

[14] Zacharia, Z. C., Manoli, C., Xenofontos, N., de Jong, T., Pedaste, M., van Riesen, S. A., \& ... Tsourlidaki, E. (2015). Identifying Potential Types of Guidance for Supporting Student Inquiry When Using Virtual and Remote Labs in Science: A Literature Review. Educational Technology Research And Development, 63(2), 257-302.

[15] Kolloffel, B., Eysink, T. H. S., \& de Jong, T. (2011). Comparing the effects of representational tools in collaborative and individual inquiry learning. International Journal of ComputerSupported Collaborative Learning, 6, 223-251. doi: 10.1007/s11412-011-9110-3

[16] Harlen, W., \& Jelly, S. (1997). Developing science in the primary classroom. Essex: Addison Wesley Longman.

[17] Zachos, P., Sargent, C., Hick, T., \& Doane, W. (2000). Setting theoretical and empirical foundations for assessing scientific inquiry and discovery in educational programs. Journal of Research in Science Teaching, 37(9), 938-962.

[18] Dyment, J. E., \& O'Connell, T. S. (2011). Assessing the Quality of Reflection in Student Journals: A Review of the Research. Teaching In Higher Education, 16(1), 81-97.

[19] Chinn, C. A., \& Brewer, W. F. (1993). The role of anomalous data in knowledge acquisition: A theoretical framework and implications for science instruction. Review of Educational Research, 63, 1-49. doi:10.2307/1170558

[20] Reid, D. J., Zhang, J., \& Chen, Q. (2003). Supporting scientific discovery learning in a simulation environment. Journal of Computer Assisted Learning, 19, 9-20. doi:10.1046/j.02664909.2003.00002.x

[21] van Joolingen, W. R., de Jong, T., Lazonder, A. W., Savelsbergh, E. R., \& Manlove, S. (2005). Co-Lab: research and development of an online learning environment for collaborative scientific discovery learning. Computers in Human Behaviour, 21, 671-688. doi: dx.doi.org/10.1016/j.chb.2004.10.039

[22] Mäeots, M., Pedaste, M., \& Sarapuu, T. (2011, 6-8 July 2011). Interactions between inquiry processes in a Web-based learning environment. Paper presented at the $11^{\text {th }}$ IEEE International Conference on Advanced Learning Technologies, Athens, USA. doi: http://10.1109/ICALT.2011.103

[23] Mäeots, M., \& Pedaste, M. (2014). The role of general inquiry knowledge in enhancing students' transformative inquiry processes in a web-based learning environment. Journal of Baltic Science Education, 13, 19-31. 